Journal of Social Sciences 5(3): 193-205, 2009

ISSN 1549-3652

(C) 2009 Science Publications

\title{
Implementing the Current Science and Citizenship Mandates: A Learning Theory Analysis and Set of Recommendations
}

\author{
Lisa Erikson and James Carifio \\ University of Massachusetts, Graduate School of Education \\ One University Avenue, Lowell, MA 01854, USA
}

\begin{abstract}
Problem statement: The purpose of this research was to use learning theory to analyze the relationships between current views of citizenship, citizenship education, science and science education to develop a reasonably coherent and integrated view and approach to science and citizenship mandates that can be successfully implemented in our schools. Approach: The three models of citizenship education currently competing for dominance in our schools were: The national forging approach, the global education approach and the deliberative democratic approach. Results: Our conclusion was that it was only the use of the nation forging approach (teaching a common core of foundational knowledge and skills in both citizenship and science education) at the elementary school level that was going to foster and help students develop the cognitive schemas and reasoning skills that are the necessary prerequisites for the Deliberative democracy approach. Conclusion: If and when students do develop the high level of knowledge and reasoning ability required to engage in deliberative democracy approach, possibly at the secondary level of schooling, then the DDA approach will, most definitely, foster and help students develop the common core cultural and deliberative skills and values that will, in turn, then allow the global education approach, with its multicultural (or rather more differentiated, nuanced and subtle if fuzzy) views, to be pursued at the post-secondary level, producing informed and deliberative citizens for this country and the world. The implications of these analyses, findings and conclusions were discussed.
\end{abstract}

Key words: Citizenship Education, Science Education, Educational Mandates, Learning and Development Theory

\section{INTRODUCTION}

Modern science is and has been (with little doubt) deeply enmeshed in all of the difficult and complex social, political and economic issues of our times ${ }^{[1]}$ and even more so in the present era of "globalization." In the context of what many sociologists have called our current "risk society," science is increasingly assuming a greater and greater role in the decision-making (from personal to social, political and economic) as an antidote to various special interests, ideologies and increasing biases in all cultures and particularly those of the institutional kind. According to many experts and scholars $^{[2,3]}$, our technologically advanced and powerfully persuasive media have become a blatantly biased and one-sided and often a scientifically, as well as historically, inaccurate force in our country rather than a reasonably objective and balanced provider of accurate and acceptably valid information on all sides of an issue or problem. To update and paraphrase
Marshall McLuhan, the media are now one of the major problems and impediments to our objective, scientific and deep understanding of current events and situations. In a word, the "medium (now) is not the (low noise and high fidelity) message".

The internet, especially, is flooded with misinformation posing as "news", "facts" and scientific studies, many of which were never done and do not even exist ${ }^{[4]}$. The over (and often mindless and ritualistic) emphasis on "diversity" and "political correctness" has created more racial, cultural, social and religious tension, as well as more problems, between the various groups in our country than 30 years ago and particularly in terms of the credibility of others, trust, civic engagement, facts and evidence ${ }^{[5,6]}$. Many experts and scholars compare us to Rome in the way that our government has allowed various economic, social, political, competitive, divisive and legal problems to get out of hand and be misrepresented (including our decline) and to create an "unscientific"

Corresponding Author: Lisa Erikson, University of Massachusetts, Graduate School of Education, One University Avenue, Lowell, MA 01854, USA 
environment and culture of "double-think", "doublespeak", "double-standards" and disregard and disrespect for our Constitutional laws, legal processes and traditions of fairness, objective data and equal consideration of rival views and hypothesis ${ }^{[7,8]}$.

It should not have come as a surprise to anyone, then, that we became a "Nation-At-Risk" and will remain so until we once again see, understand and assert that Citizenship and all it entails, is a core basic skill and requirement of every person in our country and that Citizenship and all of its responsibilities represent a core common culture and standard in our country, despite the broad, varied and endless attempts to negate this fundamental fact (in our country) over the last 20 years. Further, recent scholarship and an increasing public awareness of the ethical, practical and political dimensions of Science underscores the need of citizens to participate in the decision-making processes concerning controversial socio-scientific and sociotechnical issues as well as politico-scientific issues, debates, choices and decisions. Science today has a greater and more far reaching impact on every individual person's life, as well as all groups, industries, countries and alliances between countries. It is critically important, then, that every adult who holds citizenship in some country be able to understand the basic sciences and how to think critically about sciencebased evidence, issues, decisions and the consequences thereof. Therefore, it is the inescapable responsibility of schools in a democratic society to teach students and teachers both Citizenship Education and Science Education and the intersection and union of both. This inescapable responsibility, however, is a very tricky problem and issue for a number of reasons, which are discussed below.

The first problem that must be addressed to carry out the above mission and responsibility is to answer the questions: "What is Citizenship and what are the characteristics and skill sets of the definition of citizenship one employs in a constitutional democracy?" And the questions that must be answered next are: "How compatible is the view and definitions of Citizenship being advocated or examined to the established and mainstream definitions and views of Science and what Science is and does?" These questions are further complicated by the fact that there are currently three major models of Citizenship Education competing for dominance in the US public schools today. These three competing models are: the original Nation Forging Approach (NFA), the Global Education Approach (GEA) and the Deliberative Democratic Approach (DDA). In Science Education, the notion of citizenship has often been characterized as part of "Scientific Literacy",[9,10]. However, like the concept of Citizenship Education, the concept of Scientific Literacy is itself not at all clear, as many have pointed out ${ }^{[11]}$, even though many science educators and the scientific community believe that scientific literacy is well-defined and clear at least at a very general and non-operational level such as the "national standards". Unfortunately, this clarity is not in fact the case ${ }^{[12-14]}$.

In fact, Dagostino and Carifio ${ }^{[12]}$ identify six different kinds and domains (or spheres) of literacy (functional, specialized, cultural, multi-cultural, critical and composite world) that are increasingly complex supersets of each other. Citizenship resides in the sixth and highest Composite World Literacy domain or sphere. This sphere requires the individual to be functionally literate, to comprehend and utilize specialized literacy, to have the cultural, multicultural literacy and critical literacy to move beyond themselves to the needs and problems in our society and world. This sphere requires all of the literacies needed to solve the big issues, promote new visions and to be flexible, adaptable and inventive in every way in this everchanging world. Composite World Literacy is a bit like Kohlberg's ${ }^{[15]}$ Stage 6 (Universal Ethical Principles) in which an individual acts out of broad and general principles based upon the equality and worth of all human beings. Having rights means that every individual is due consideration of his interests in every situation, those interests being of equal importance with one's own ${ }^{[16]}$. Kohlberg originally theorized that at most, $25 \%$ of human beings develop to Stage 6 and he has since 1983 dropped this stage altogether. Therefore, this article will focus on and discuss citizenship and scientific literacies that may actually be taught and learned in our public school systems and how they relate to one another.

Scientific literacy: Putting some of the intractable issues of the science wars aside, the modern (standardsbased) view in science education defines scientific literacy in part as "the knowledge and understanding of scientific concepts and processes required for personal decision making, participation in civic and cultural affairs and productivity" ${ }^{[10]}$. This form of literacy is inextricably linked to the science content taught in schools and what scientists' know, work on and produce $^{[11]}$. Thus, there are certain content areas of science that must be "covered" in our classrooms, such as biology, chemistry and physics and covered in terms of their basic knowledge, processes, methods, assumptions and resultant products. Yet, as the National Science Education Standards point out, irrespective of their scientific backgrounds, students and citizens are 
now faced with engaging and using science in a myriad of ways. Science and the work of scientists are, for example, related to: (1) Economic development: e.g., pharmaceuticals, information technology, corporate citizenship or lack thereof; (2) Environmental issues: i.e., balancing the work that scientists are doing to create new ways to recuperate and safeguard the quality of the environment versus the "needs" of industry and individuals; and, (3) Social issues: i.e., developments in scientific research that contribute to the quality of life but what are the social, moral, ethical and political implications of research. Thus, one emerging view is to frame a more general view of (democratic) citizenship and ask what kind of scientific literacy can contribute to this view and its implementation. Given this more generalized view, then, the mission of science education, like citizenship education, both in schools and as a lifelong learning endeavor, must be to inhibit the populace from being passive, accepting and uncaring spectators (which will be the death-knell of our democracy) and to teach students to be aware, to think critically, to care for the common good and the future and to engage in reasoned and evidence-driven decision-making and action.

Purpose: The purpose of this article is to use learning theory to analyze the relationships between current views of Citizenship, Citizenship Education, Science and Science Education to develop a reasonably coherent integrated view and approach to science and citizenship mandates that can be successfully implemented in our schools. Critical Analysis theory and methodology ${ }^{[17]}$ was used to carry out these examinations.

Critical analysis theory and methodology merges several theories, models and methods together to perform acts of "complex cognition(s)" on "complex and usually fuzzy and convoluted phenomena". One of the "root" theories and methodologies of Critical Analysis Theory is that of analytical philosophy and philosophical analysis. The next root of critical theory and analysis is the area of theory construction and theory analysis, which developed rapidly in the 1970's after a great leap forward in the 1950's. The third component of Critical Analysis Theory and methodology derives from Flanagan's Critical Incident methodology, which seeks to identify key qualitative factors, dimensions, events, or concepts of varying kinds relative to a given problem. The last major root of Critical Analysis Theory comes from the fields of literary and textual criticism. Various formal theories and techniques of literary criticism and scholarship explicitly identify a particular "canon" or lens which is used to "deconstruct", analyze, evaluate and compare individual works, collections of works, genres and views or messages. Consequently, the theoretical lenses used to carry out the current critical analyses were the theories of Piaget, Kohlberg, Erikson, Carifio and Dagostino and Carifio ${ }^{[12,15,18-20]}$. These researchers and each of these five major lens are aligned with each other by age and are summarized in detail in Lisa Erikson's ${ }^{[21]}$ dissertation, along with a fuller explication of Critical Analysis theory and methodology.

Given the complexities and number of ideas, concepts and issues that will be introduced and interrelated in this article, the three major approaches to Citizenship Education currently competing in American public schools will first be discussed and analyzed in some detail. These three approaches are: the original Nation Forging Approach (NFA), the Global Education Approach (GEA) and the Deliberative Democratic Approach (DDA). Next, we examine how Science and Science Education are inextricably related to the implications of these different Citizenship approaches, which will be followed by an examination of how the various interrelationships of these aforementioned fundamental concepts or units relate to scientific and other kinds of literacy. However, to accomplish these tasks, both views of citizenship and citizenship education, as well as of science and science literacy must also be related to theories of learning and development, as these considerations are typically absent from and unconsidered by these views, which is a major part of the problem in this area ${ }^{[21]}$. A brief summary of these three approaches to Citizenship Education is given for those who are unfamiliar with these models, so that discussion may proceed to how these approaches relate Science education and literacies and the mandates of educational reform relative to Science and Citizenship objectives. Table 1 presents a summary of the chief characteristics and criticisms of these three Citizenship Education models and approaches and Table 2 shows the comparative alignment of these three major competing approaches to Citizenship Education in America for the reader.

The nation forging approach: The Nation Forging Approach to Citizenship Education includes the set of goals and ideals that were needed to create, build and maintain this country (and communities within it) that now need to be taught to our children today: Namely, "cooperation, courage, hard work, honesty, justice, perseverance, self-reliance and respect of oneself and others" "22]. Certainly all of these attributes of citizenship must be considered essential with respect to science and the conduct of science as well as scientific literacy. 
Table 1: A summary of the three major current approaches to citizenship education

The nation forging approach:

1. US history as an exemplar of good citizenship

2. English as the national language

3. Identification of oneself as an American, a US citizen Major criticisms of the nation forging approach are that it is based on hero worship; centrist assumptions; and Idealism

The global education approach:

1. Multiculturalism

2. Cultural relativism

3. Global citizenship

Major criticisms of the global education approach are that it is anti-United States; cultural relativism and the costs: Economic, social and political

The deliberative democratic approach to citizenship education:

1. Five components of democratic deliberation

2. Beyond a social contract: A moral contract

3. Similarities to and differences from the nation forging approach Some criticisms of the deliberative democratic approach are the cost and feasibility in public schools; its political ambiguity and its ignorance of moral development theory

Table 2: Comparative alignment of the major competing approaches to citizenship education in America

\begin{tabular}{|c|c|c|}
\hline $\begin{array}{l}\text { Nation Forging } \\
\text { Approach (NFA) }\end{array}$ & $\begin{array}{l}\text { Deliberative Democratic } \\
\text { Approach (DDA) }\end{array}$ & $\begin{array}{l}\text { Global Education } \\
\text { Approach (GEA) }\end{array}$ \\
\hline $\begin{array}{l}\text { Traditional } \\
\text { approach: }\end{array}$ & Supported by & Multiculturalism: \\
\hline $\begin{array}{l}\text { Using American } \\
\text { history and } \\
\text { "civics" classes } \\
\text { to education } \\
\text { teach citizenship }\end{array}$ & $\begin{array}{l}\text { Academic } \\
\text { community: } \\
\text { Guttmann, } \\
\text { Macedo, for } \\
\text { example }\end{array}$ & $\begin{array}{l}\text { Teaching students } \\
\text { about various } \\
\text { cultures } \\
\text { Using equal or } \\
\text { greater amount } \\
\text { of time as spent } \\
\text { on "American } \\
\text { Culture" }\end{array}$ \\
\hline $\begin{array}{l}\text { Used in our } \\
\text { Schools for } \\
200 \text { years to } \\
\text { maintain } \\
\text { democracy and } \\
\text { democratic ideals }\end{array}$ & $\begin{array}{l}\text { Adds a moral } \\
\text { component to } \\
\text { citizenship }\end{array}$ & $\begin{array}{l}\text { Cultural relativism } \\
\text { Teaching students } \\
\text { that no one culture } \\
\text { is better than } \\
\text { another }\end{array}$ \\
\hline $\begin{array}{l}\text { Advocates a } \\
\text { common } \\
\text { language }\end{array}$ & $\begin{array}{l}\text { Decisions and } \\
\text { laws made through } \\
\text { democratic deliberation }\end{array}$ & $\begin{array}{l}\text { Advocates } \\
\text { Bi-Lingualism }\end{array}$ \\
\hline $\begin{array}{l}\text { Identification as } \\
\text { United States } \\
\text { citizen }\end{array}$ & $\begin{array}{l}\text { Good of many } \\
\text { supersedes } \\
\text { Individual rights }\end{array}$ & $\begin{array}{l}\text { Global citizenship } \\
\text { "Transnational } \\
\text { progressivism" }\end{array}$ \\
\hline
\end{tabular}

Consider the many aspects of our lives that are directly influenced by science today, which has become a basic component of both our culture and our economy. As previously stated, the work of scientists directly influences economic development, environmental issues and the social implications (and impacts) of how scientific findings, discoveries and inventions contribute to the quality of our lives, as well as the social, moral and ethical issues and decisions we must face and make.

All major philosophies, psychologies and religions of all known cultures hold that rules, values and proper behaviors are learned and, therefore, can be taught. Children are not born knowing the rules, values, ethical imperatives and the laws of their nation. Also, as Kant stated, "There are two human inventions which may be considered more difficult than others- the art of government and the art of education; and people still contend as to their very meaning" "[23]. Therefore, this common set of ideals was and still should be part of the "American Dream" and taught in our public schools in both Citizenship Education and Science Education.

The nation forging approach also contends that there must be a common language for all citizens, interactions and transactions (i.e., English, for several different important reasons, including that the science and technological communities use English). In addition to learning English, the Nation Forging Approach contends that citizens, immigrants or not, need to begin or continue to identify themselves proudly as Americans, a process that is very similar to the process of being inducted into a given scientific discipline and community ${ }^{[24,25]}$. Pledging allegiance to the US flag, allegiance to this country and other such solidarity indicating behaviors are vitally important in this time of political and social difficulty. Social critics, including the political philosopher Jean Bethke Elshtain $^{[26]}$, write that social integration and cultural induction and assimilation are being held back by "white guilt" or fear of criticizing multiculturalism ${ }^{[5]}$. Science also supports the notion and view of a common public working language for scientists, as well as a commitment to the basic and core values of science and the community of science. Science is also sensitive to problems and difficulties in its induction, enculturation and assimilation processes and consciously and somewhat scrupulously attends to these three processes in order to forge a "nation" of new scientists. These aspects of Science, therefore, both support and reflect the Nation Forging view of Citizenship education.

The Nation Forging Approach has been challenged by many ${ }^{[27,28]}$ for portraying history through the eyes of white, European males as heroes. This criticism is especially strong from proponents of the global education approach to citizenship education (which will be discussed next). By the 1960's, issues such as bilingual instruction, multicultural curriculums, lack of female, black and other types of heroes, new gender policies, sex education, prayer in schools and so on, became subjects of intense scrutiny in how to teach Citizenship Education in public schools. With an excessive "hero focus", one can see why everyone who does not fit the "traditional" profile wants to have their heroes in the established pantheon. It is true that in the past, the Nation Forging Approach (like each scientific 
discipline) has not done a proper job in recognizing all the peoples who have forged this nation and revisions were necessary. However, the content of the nation forging approach need not be white male hero-centered or even confined to heroines and the heroic. The history and stories chosen to depict, portray and teach the core values, characteristics and contributions of our country can be a broad range from the millions of everyday people who contributed to forging this democratic country. Similarly, science education and science in our country has made remarkable strides in inclusiveness, diverse role models and opportunities and has done so without throwing out the "nation forging" view of either science or citizenship. In fact, it has strengthened these core views by its inclusiveness and its recognition that all citizens need these core literacies and for this it should be commended.

Another of the most significant critiques of the nation forging approach of Citizenship Education contends that this approach is embedded in Centrist Assumptions about liberal democracy ${ }^{[29,30]}$. The Deliberative Democratic Approach (3rd to be examined) criticizes centrist assumptions that are based on the belief that the existing systems of government and schooling are successful. A Centrist approach in curriculum and pedagogy includes little inquiry into current institutions, practices and content. "Everything about these institutions is taught as a given" $"$ [30] Yet, according to learning and developmental theorists like Piaget, when children are in elementary school, it is important for them to have consistency. Elementary schools must teach the "basics" of citizenship, math, English and science, in order for students to have a foundation for developing higher level thinking skills. There are certain facts and fundamentals that students must learn: math facts, the laws of our country and basic topics in science, such as learning about the interaction between human being and plant life; different materials that exist, their properties and behavior on a small dimension as well as a larger dimension including the Earth and Space and the properties of sound, electricity, light and forces and motion. But a very important point that needs to be well-noted here is that science and particularly Kuhnian "normal science", is a centrist endeavor and discipline and particularly so though its use of standard models and paradigms and realistic and objective epistemologies for the conduct of every day business. The point here is that a centrist approach is not necessarily a "bad thing" and is quite often a very good thing and what is needed to solve problems and advanced our understanding of different situation and phenomena. Certainly, then, "centrism" is not incompatible or incommensurate with science or scientific literacy.

It has also been argued that even educational programs that encourage active student participation and require students to engage in real-life problems do not question the content that is taught ${ }^{[3]}$. However, as mentioned above, the Nation Forging Approach to Citizenship Education is open to having its content reexamined in terms of greater inclusiveness and pedagogical practices and in terms of being experimental and evidence-based. It is both a fact and a fundamental that students need to learn the constitution, the bill of rights and other historical documents that cannot be disputed for their thinking, values, opinion formation and decision-making to be evidence-based and evidence-driven in our democratic society and country as opposed to ideological and/or orthodoxydriven thinking.

Further, as the European Union grows and projects its influence, our hemisphere becomes more vulnerable to global turmoil ${ }^{[31]}$. European and other transcontinental alliances have been formed with our neighbors. Canada and Britain, France and Germany, all possessing growing fundamentalism and/or socialistic trends from various religious, ideological social and economic models that may soon pose a threat to the US ${ }^{[32]}$. The United States has the "democracy" that immigrants want to come to from choice because of the rights and responsibilities offered in our core governing documents and these documents are the evidence foundation that are to be used to guide, decide and judge behavior, as opposed to unsupported attributions and claims. Teaching all children in this country about the basics of our historical founding and laws is essential to this country's survival and daily renewal and the daily conduct of its business and various enterprises. There must be a set of common core beliefs, practices and obligations ${ }^{[33]}$ for all American citizens if we are to develop a common and unifying civic identity, which can be the cohesive, stable and enduring core of a multicultural society. A functioning and successful society (like that of the science community) can only be maintained if citizens can communicate and cooperate in terms of a common civic culture and a set of common civic duties and responsibilities ${ }^{[34,35]}$. All of these behaviors, traits, attitudes, values and responsibilities must be learned and learned earlier rather than later. Science is and has been a proponent of a unifying (civic) identity and common core culture since the Ancient Greeks ${ }^{[25]}$ and, in today's society, it is probably one of if not the major vehicle by which students encounter and learn all of the points made above. 
Global education approach: The second major view of citizenship education, the global education approach, says that we must take into consideration the multicultural nature of our citizenry and economic globalization, which, according to the GEA's ideology, makes it impossible to retain the old fashioned belief of nationalism and our citizenry's identification as "American", as we are "all now citizens of the world" ${ }^{\text {[36] }}$. The Global Education Approach underscores the importance of multicultural education in our schools because of increased global interdependence and the shifting international balance of power. Some recent examples of international developments that have direct ramifications for the continuous leadership of the United States in global affairs are: the challenges to US dominance of the world's marketplace by Japan, Germany and Korea; military crises in the Middle East that affect the oil supply and reserves as well as world peace; the US fiscal resource allocations between military and social services expenditures; governmental instability in South and Central America, which places incredible demands on US military support and foreign loan capacity; famine and droughts in Africa and Asia that require US support in health care and food supplies; increasing birth rates, epidemic illnesses and human rights issues around the globe; and growing foreign investments in the United States. These developments mean that US citizens must interact in different ways and under different circumstances with unfamiliar peoples at home and abroad. Successful interactions and relationships require the use of knowledge, attitudes and skills about cultural diversity within a global context (and a lot of science as well, which is rarely acknowledged or even mentioned by those who espouse this view). The success of US international diplomacy is becoming increasingly dependent upon knowledge and principles of cultural pluralism $^{[37,38]}$. The Global Education Approach in Citizenship Education contends that it can create a foundation for effective and successful diplomacy in the global context.

In terms of relating the GEA view to science and science education, the notion or idea that there are many kinds or flavors of physics or chemistry, or any other hard science that must be accommodated and included (and maintained) by fiat is not a zeitgeist or view that is espoused in science or its everyday conduct. All is not "relative" or pluralistic in science and such a position is the nexus of both conflict and contradiction when it comes to science and multicultural citizenship views and concepts. Science only allows so much diversity and only so many kinds of "truths" with clear limits and criteria for both and science actively and explicitly excludes and weeds out, again with clear criteria and standards for doing so, many views, alleged facts and truths and explanatory claims and science rarely accepts or tolerates eclecticisms, eclectic views, or fundamental inconsistencies and science actively works to eliminate them from each discipline and science as a whole. The very nature and essence of science is that it is neither "multi-cultural" nor "pluralistic" in any broad or inclusive way ${ }^{[24,14]}$, which poses many problems and difficulties for the GEA view and approach.

Another aspect of the global education approach is to help counter, in this country, the dominance of Anglo-centric and middleclass cultural values. Most school structures and procedures are grounded in mainstream cultural conceptions of law, order, reason and rationality. The global education approach contends that if one of the primary functions of schooling is to transmit the socio-cultural legacy of the nation to its young citizens, then our educational system must incorporate Multiculturalism as a persistent and routine component of programs and practices. The GEA also contends that in addition to mastering basic reading and writing skills, literate citizens in democratic, multicultural societies such as the United States, Canada and the United Kingdom should develop multicultural literacy ${ }^{[39]}$.

"Multicultural literacy" consists of the skills and abilities to identify the creators of knowledge and their interests, to uncover the assumptions of knowledge, to view knowledge from diverse ethnic and cultural perspectives and to use knowledge to guide action that will create a humane and just world ${ }^{[39]}$. Although this is undoubtedly a wonderful goal, when one delves into other components of the Global Education Approach, they are inconsistent with learning and developmental theories and the practices that it preaches seem more divisive than conducive to open communication and cooperation and this point is exactly what the most recent objective and empirical scientific research shows ${ }^{[5,6]}$. Further, science has a very well established and well-tested method and process for arbitrating differences of belief, opinion and fact than the multicultural view and the two will never be reconciled despite all the claims and attempts to do so by epistemologists, sociologists and others.

Like "citizenship" and "scientific literacy", defining the term "multiculturalism" can be difficult, as there are many different views and perceptions. As with any dialogue on education, individuals tend to mold concepts to fit their "special interests". The best definition for the goals of citizenship and science education in this model is called Holistic 
Multiculturalism ${ }^{[39]}$ which stresses the idea of cultural pluralism, defined by Diane Ravitch ${ }^{[7]}$ as a view that the maintenance of many, or "plural", cultures housed within a nation's "ethnic groups" is valuable, both to the ethnic group (as well as to its individual members) and to the host nation (as a whole).

In the United States, the traditional view had been one of a "melting pot" where all the immigrant cultures are mixed and amalgamated. The current view is that of a "salad bowl" model, which recognizes that we are a nation of immigrants from many different places, but have a national "dressing" that is "American". Holistic Multiculturalism has also been described by proponents as preserving a "cultural mosaic" of separate ethnic groups while creating a single piece of art. In the Holistic sense, then, Multiculturalism has come to be a shorthand term for a form of cultural pluralism. Holistic Multiculturalism asks for comprehensive school reform and basic education for all students that challenges all forms of discrimination, permeates instruction and interpersonal relations in the classroom and advances the democratic principles of social justice ${ }^{[40]}$. As previously stated, science allows for different views and diversity, but implicitly understands that both have limits and eventually must be decided and reconciled against core standards and through testing. Like the nation forging approach to citizenship education, science does not seek to preserve forever all forms, even forms of its past, for their own sake. Such preservation would be politics rationalizing science rather than the other way around. It is not surprising to us at least that there is and has been so many tensions and indirect and direct skirmishes between scientists and science educators and the proponents of the GEA views and approach as there are many fundamental incompatibilities between the two.

Additionally, the type of multiculturalism that is promoted by the global education approach to citizenship education is not holistic multiculturalism but rather some form of political multiculturalism. Political multiculturalism opposes the assimilation of immigrants into the nation's culture and is more concerned with preserving the distinctions between cultures, deliberately encouraging immigrants (and their offspring) to remain within society as separate "ethnic" groups. The global education approach believes that multicultural programs are necessary in our public schools to help our youth value and celebrate diversity. This view is called "Particular Multiculturalism" by Diane Ravitch ${ }^{[7]}$. Political Multiculturalism wants to engage in social actions to institutionalize multicultural values and practices, thereby helping society "live up to both the letter and spirit of this nation's democratic ideals ${ }^{\text {"[41] }}$ by preserving or promoting cultural integrity and authenticity. So, it is very important to define what "multiculturalism" means in any discourse related to education to avoid a myriad of confusions.

As stated above, this static Political Multiculturalism is antithetical to science and how science works, grows, develops and settles differences and develops consensus views and paradigms. Consequently, this "Particular" or "Political" Multiculturalism is going to be very problematic for the teaching of science and its intersection with citizenship, particularly in relation to "rights" or views in conflict as well as the "facts and fundamentals" and the induction and enculturation processes of science. It is not surprising to us that there have been many difficulties teaching science successfully, to elementary students in particular as well as secondary school students, within the context of the GEA view and approach, which is the dominant approach now in our the United States at the K-12 level.

Cultural relativism is the second major component of the global education approach, namely, "that each culture is of equal value and should not be judged from the cultural perspectives of others" ${ }^{[42]}$. In this manner of thinking, all cultures are "equal" (which is not exactly how science would pose, characterize or pursue this issue or question and particularly so a scientist like Darwin or Geller-Mann). Further, GEA adherents maintain that it cannot be said that other cultures, or certain cultural customs, are "wrong" or "inferior", as to do so would be to act "culturally superior" or, at worst, even "racist". The Global Education Approach calls on immigrants to retain their "Old Country" values intact, as "priceless heirlooms" [43]. The incredible irony here, relative to the Global Education Approach, is that the nation forging approach is trying to retain the United States' "Old Country" traits of democracy and a culture of diversity with cooperation. The global education approach rejects and demeans this heirloom, apparently expecting that focusing on their differences instead of motivating children to look for the similarities in one another will best serve our children. Orthodoxies, however, seldom perceive or understand their "blind spots", although understanding one's blind spots (for example by testing various falsification hypotheses) is one of the most important aspects of scientific experiments, developments and acceptability by the "scientific community"[44].

The Nation Forging Approach to Citizenship Education views Cultural relativism as a major hindrance to a cohesive, functioning and successful American society and culture. For the Global Education Approach's purposes, it is seen as imperative that 
"multiculturalism" and cultural relativism as ideals are taught to children in their formative years, so as to shape the views of the coming generations ${ }^{[28]}$. However, according to Erikson ${ }^{[19]}$ and other development psychologists $^{[45]}$, children cannot cognitively nor emotionally hold multiple identities and, therefore, our public schools must concentrate on creating the "salad dressing" to unite students in their formative years. Also, within the United States, the achievements of Asians and Jews, who had no multicultural curriculum designed to make them feel better about themselves, are well documented $^{[46,47]}$, but not at all well publicized, which is not a hallmark of science or the processes by which it conducts itself and works. Further, in their search for recognition, various 'minorities' or "underrepresented" people, have fostered a substantial amount of "white guilt" among the "majority" or predominant culture. To this end, cultural relativism is now being reflected in all subject areas. In fact, the National Education Association suggested that teachers avoid placing blame on anyone for the 9/11/2001 attack on our nation and to discuss what the United States had done to provoke the attack ${ }^{[48]}$. One of the most articulate critics of cultural relativism is the political theorist Brian Barry ${ }^{[49]}$, who argues that this aspect of multiculturalism divides people when they need to be united in order to fight for social justice, or in the USA's case, democracy. Science and particularly the learning and psychological sciences, then, have a lot to say about all of the points above that somehow gets excluded from all these debates (similar to achievement data about Jews and Asians), which is in itself an "interesting" fact. The Global Education Approach does not accept the core modern scientific concept of falsification and evidence that falsify its claims, or the incorporation of falsification principals and designs into the conduct of its activities, examination of its claims, or the evaluation of evidence. Reconciling modern science and the GEA view and approach, even in a very fuzzy fashion, is not going to be an easy thing to do and particularly so for K-12 students. Those familiar with the history of science in Russia and China in the last century will understand the dangers and consequences of certain kind of political models rationalizing science rather than the other way around.

Lastly, many proponents of Global Education Approach in its different forms also embrace "Transnational Progressivism""[50], which contends that, "citizenship can no longer be understood as the pursuit of the homogeneous nation-state"[41]. Transnational progressivism endorses the concept that new civic ideals, international in reach and a shift of focus to global trends and problems is necessary for citizens to be able to function in an increasingly interdependent world $^{[50]}$. Therefore, it is important, according to this approach, that schools teach students to be "transnational" citizens. This aspect of the global education approach has a great deal of appeal in terms of the scientific community, by taking us back to the 1930's and 1940's in both science and the world, when sharing new knowledge was the norm and a way of keeping power situations "balanced" and "neutralized", which can be traced back to DaVinci's views of the social responsibilities of inventors to invent and make available any new invention or innovation that would or could significantly alter or tip the balance of power in various situations that would result is major harm or harmful consequences. But the world is very different today and these critical differences and conflicts change the validity and realistic expectations of gaining worldwide cooperation in transnational progressivism and science, particularly as expressed through multi-national corporations. The ever accelerating trend of the close alliances between science, scientists and multi-national corporations and their actions and ventures on both a local and international scale, require more than ever before in our history that our scientists be United States citizens and the best of our citizens and that they be explicitly be taught to be so from elementary school to graduate school and across the span of their scientific careers. This point is easy to understand with the current international debates surrounding nuclear power ${ }^{[31]}$.

Deliberative democratic approach: According to Gutmann $^{[51]}$, a proponent of the third citizenship education approach (the deliberative democratic approach) unity must be a primary goal in responding to diversity within the USA. Unity is a core value of science. Only if everyone is united around a set of democratic values, such as justice and equality, can the rights of "minorities" be protected and the voices of diverse groups be heard and equally considered. One of the DDA's chief criticisms of the GEA approach is that instead of focusing on building a common core and civic identity, the GEA opts instead to encourage the division into and divisiveness of multicultural groups.

Deliberative Democracy has a long history, with origins in Kant and has been developed by John Rawls, Jurgen Habermas and Hannah Arendt, as a means for citizens, even when they strongly disagree, to at least agree to deliberate rationally over their differences. Agreeing to a method with explicit rules, standards and criteria to answer questions and resolve disputes and arbitrate claims and views is the very hallmark of science and the scientific method, as it has evolved over the centuries into its most modern form, as opposed to a 
political or power approach to diversity, disputes, conflicts and the settling disagreements and the soundness of differing view, contentions and proposals for action or policies. According to the DDA model of democratic politics, citizens do not have to share values or views. However, they need and must be able to share ideal communicative procedures, standards and processes for decision making. The Deliberative Democratic Approach highlights the way that democratic legitimacy depends on the ability and/or opportunity to participate in rational deliberation on the part of those citizens subject to collective decisions ${ }^{[52,53]}$. As Amy Gutmann has continually stated, "Education in character and moral reasoning are therefore both necessary, neither sufficient, for creating democratic citizens" "[54]. Thus, the deliberative democratic approach insists that students must be taught how to think critically about public affairs and must participate fully in the democratic process through deliberation. This view is very close to what the emerging views of scientific literacy calls for: namely, that educators need to provide a science education that fulfils the need to have scientifically literate citizens such that they (citizens) can understand the environmental, social, ethical and moral implications of scientific activity and be capable of understanding scientific issues and making independent and informed judgments on scientific developments and knowing how to exercise their rights and take action as active citizens.

Stephen Macedo ${ }^{[55]}$ another advocate of the deliberative democratic approach, in his book Diversity and Distrust: Civic Education in a Multicultural Democracy states that:

- Liberalism is about placing liberty and the defense of basic human rights at the center of the political project. The freedom to choose, to pursue diverse religious and philosophical conceptions, is central to liberalism. But a liberal democratic society also counts on channeling the way people use their freedom. Liberalism properly understood is anything but neutral with respect to basic moral and political issues and it does stand for an ultimate commitment to fairness and impartiality. Liberalism as a system of free self-government needs to encourage wide-spread convergence on certain shared attitudes and character traits, as well as the patterns of social life that support them.

It is interesting to note how similar Macedo's description and characterization of "liberalism" given above is to the characterization of the several of the essential features of science by many leading philosophers of science and to the characterization of science presented in the Nation Forging section of this article. Thus Macedo, a proponent of Deliberative Democracy believes (like the Nation Forging Approach), that the US institutions and traditions of liberalism, as he defines them, require a commitment to and faith in civic purposes if we are to maintain and defend our country and democracy. Consequently, reasonable efforts to inculcate shared political virtues are incompatible with the "Cultural Relativity" of the Global Education Approach. The deliberative democratic approach and the nation forging approach to citizenship education are very different from the Global Education Approach in that they agree that the US citizens have to continue to live by our (perhaps idealistic) moral and political values, even if others in the global community do not. As an example, both Gutmann $^{[54]}$ and Macedo ${ }^{[55]}$ believe that, because good citizens ought to be thoughtful and deliberative ones, public schools can legitimately turn down requests by fundamentalist parents not to have their children exposed to literature they consider irreligious or immoral. All students must learn the same nonrelativistic core values and gain the intellectual and moral capacities to practice those deliberative democratic virtues.

And how can Science Education assist in these goals? Gutmann ${ }^{[54]}$ writes that, "People who possess moral character without a developed capacity for reasoning are ruled only habit and authority and are incapable of constituting a society of sovereign citizens". So, first teach and then over-teach the scientific method to help develop the reasoning capabilities of all students. According to Driver ${ }^{[56]}$, students must learn to: (1) Observe and describe the facts of a phenomena or group of phenomena; (2) Develop a hypothesis, or idea to explain the phenomena; (3) Use the hypothesis to predict the existence of other phenomena or to predict the results of new observations; and, (4) Perform experimental tests of the predictions and try to come to some conclusions. Once these reasoning and deliberation skills are second nature to them ${ }^{[57]}$, students and citizens will be more competent to enter the public (political) discourse, whether it surrounds controversial scientific issues or other controversial social and political issues. Although Gutmann agrees that we must use our schools for "social and political reproduction", she also feels that continuous deliberation must take place even as to what are fair procedures, individual rights and, even perhaps, constitutional issues. Getting students to learn how to reflect will help them develop the skills they need in order to be active citizens. Thus, Scientific 
Literacy has to aim beyond just teaching knowledge; beyond teaching the process of science; and start including the social aspect of science and reasoned reflection as part of science education.

Implicit in Amy Guttmann's view and definition of citizenship is the idea that what is need in science education is a number of books (or/and instructional units) such as Profiles in Courage (and character) in science for students to read, study, deliberate and discuss rather than cherry-picking instances of scientists with various other characteristics to pepper through text and materials as salad dressing. Much more is needed, according to Guttmann to both link and bond science and citizenship and to do so for students. Further, science literacy is a shared responsibility of the curriculum and it is time that other courses (e.g., history and social studies) begin to more seriously and consistently address issues of science, scientific reasoning and scientific discovery which have shaped and continue to shape our social, cultural and political landscapes. Without an interdisciplinary and multidisciplinary view and approach to science literacy, students lose the opportunity for sustained learning and application of key scientific concepts in a number of classroom mediated contexts.

The problem with the Deliberative Democratic Approach is that it assumes a fairly high level of cognitive development on the part of the student and is completely silent as to how this level of development comes about, other than naturalistic maturation processes (i.e., the "Here a miracle occurs..." comment one sees in humorous cartoon representations of many "scientific" theories and views). This same point holds true for the Global/Multicultural Approach in all its various forms. The simple fact is that only the use of the Nation Forging Approach, teaching a common core of foundational knowledge and skills, in both Citizenship and Science Education at the elementary school level is going to foster and help students develop the cognitive and reasoning skills that are necessary prerequisites for Deliberative Democracy. If and when students do develop the high level of knowledge and reasoning ability required to "Deliberate Democratically", this approach will, then, foster and help them develop further the common core cultural and deliberative skills and values. This, in turn, will then allow the Global Education Approach, with its multicultural (or rather more differentiated, nuanced and subtle if fuzzy) views, to be pursued at the postsecondary level, producing informed and deliberative citizens for this country and the world. These citizens will have achieved the Composite Literacy level in the model of literacy developed by Dagostino and
Carifio $^{[12]}$. This differentiated view we have presented here also harkens back to Bruner' ${ }^{[58]}$ seminal and timeless insights on the relationships between cognitive development, type of instruction and nature and representation of the type of content, knowledge, skills, attitudes and values to be learned. All of the aforementioned instructional components change with each level of cognitive development.

\section{CONCLUSION}

The purpose of this article was to use learning theory to analyze the relationships between current views of Citizenship, Citizenship Education, Science and Science Education to develop a reasonably coherent integrated view and approach to science and citizenship mandates that could be successfully implemented in our schools. The three major approaches to Citizenship Education currently competing in American public schools, the original Nation Forging Approach (NFA), the Global Education Approach (GEA) and the Deliberative Democratic Approach (DDA), were first discussed, analyzed and compared in detail (Table 1 and 2). Next, how Science and Science Education are inextricably related to the implications of these three different Citizenship approaches was examined and related to the view of scientific literacy. Additionally, both views of citizenship and citizenship education, as well as of science and science literacy were related to theories of learning and development, as these considerations are typically lacking from and unconsidered by these views, which is a major part of the problem in this area ${ }^{[19]}$. Critical analysis methodology ${ }^{[17]}$ and five major learning theory lenses were used to carry out these tasks. The details of these five major theoretical lens and a more comprehensive analysis of the three models of citizenship education summarized here is available in Erikson's ${ }^{\text {[21] }}$ dissertation.

The conclusion that was arrived at as a result of the analysis conducted was that it is only the use of the Nation Forging Approach, teaching the common core of foundational knowledge and skills, in both Citizenship and Science Education, at the elementary school level, that is going to foster and help students develop the cognitive and reasoning skills that are necessary prerequisites for the Deliberative Democracy approach. If and when students do develop the high level of knowledge and reasoning ability required to engage in Deliberative Democracy, possibly at the secondary level of schooling, then the DDA approach will, most definitely, foster and help them develop the common core cultural and deliberative skills and values that will 
in turn then allow the Global Education Approach, with its multicultural (or rather more differentiated, nuanced and subtle if fuzzy) views, to be pursued at the postsecondary level, producing informed and deliberative citizens for this country and the world. These citizens will have achieved the Composite Literacy level in the model of literacy developed by Dagostino and Carifio $^{[12]}$. There is, then, no one single, uniform or constant answer to all of the questions posed at the beginning of this article about science and science education and citizenship and citizenship education and the intersections and unions of all of these different elements or integration into a coherent whole. The "answer" is a developmental answer and model that is differentiated and strongly linked to human development theory and modern learning theory ${ }^{[20]}$ and is more akin to a phase change qualitative model that progresses from the unify fundamental core of science and citizenship through the other stages with a strong and equal focus on intellectual, knowledge and skill development as well as character development and valuing at each stage. This model and view, however, will meet with a great deal of opposition, particularly at the K-12 level, as Science Education is currently riddled with many "core contradictions", exacerbated by political/sociological pressures ${ }^{[59]}$. The very same point is also true of Citizenship Education, where there is no developmental view or modern learning theory views at all and the battle is for hegemony and the dominance of one view across the board in all situations and particularly relative to educating students and citizens. The differentiated and developmental model outlined in general here is what is needed and we as good citizens and good scientists need to engage in the appropriate processes necessary to get this model and view heard and heard widely and broadly and to be fairly considered and deliberated reasonably so that informed decisions about future educational practices, relative to both science and citizenship, in our schools can be made.

\section{REFERENCES}

1. Restivo, S., 1998. Modern science as a social problem. Soc. Problems, 35: 206-225. http://www.jstor.org/stable/800619

2. Susan, V., 2001. Impact of media on children and adolescents: A 10 year review of the research. J. Am. Acad. Child Adolesc. Psychiatry, 40: 392-401. http://www.ncbi.nlm.nih.gov/pubmed/11314564

3. Bandura, A., 1986. Social Foundations of Thought and Action. Englewood Cliffs, Prentice Hall, New Jersey, ISBN: 013815614X, pp: 617.
4. Sommers, C., 1995. Who Stole Feminism?: How Women Have Betrayed Women. Simon and Shuster, New York, ISBN: 0684801566, pp: 320.

5. Putnam, R., 2001. Bowling Alone: The Collapse and Revival of American Community. Simon and Shuster, New York, ISBN: 0743203046, pp: 541.

6. Sailer, S., 2007. Fragmented future: Multiculturalism doesn't make vibrant communities but fragmented ones. Am. Conserv., 14-21. http://www.amconmag.com/article/2007/jan/15/00007/

7. Ravitch, D., 2004. The Language Police: How Pressure Groups Restrict What Students Learn. Random House, New York, ISBN: 1400030641, pp: 267.

8. Schlesinger Jr., A., 1991. The Disuniting of America: Reflections on a Multicultural Society. Whittle Communications, New York, USA., ISBN: 0393033805, pp: 160.

9. Laugksch, R.C., 2000. Scientific literacy: A conceptual overview. Sci. Educ., 84: 71-94. DOI: 10.1002/(SICI)1098-237X(200001)84:1

10. National Research Council, 1996. National Science Education Standards. Academic Press, Washington, DC., ISBN: 0309053269, pp: 262.

11. De Jong, O., E.R. Savelsbergh and A. Alblas, 2000. Teaching for scientific literacy: Context, competency and curriculum. Proceedings of the International Utrecht/ICASE Symposium, Oct. 1113, CD- $\beta$ Press, Utrecht, pp: 144. http://www.eric.ed.gov/ERICWebPortal/custom/po rtlets/recordDetails/detailmini.jsp?_nfpb=true\&_\& ERICExtSearch_SearchValue_0=ED454097\&ERI CExtSearch_SearchType_0=no\&accno=ED454097

12. Dagostino, L. and J. Carifio, 1994. Evaluative Literacy and Reading: A Cognitive View. Allyn and Bacon, Boston, ISBN: 0205140289, pp: 142.

13. Sardar, Z., 2000. Postmodern Encounters: Thomas Kuhn and the Science Wars. Icon Books, ISBN: 10: 1840461365 , pp: 80.

14. Wilson, E.O., 1998. Back from Chaos. Atlantic Monthly, 281: 41-62. http://direct.bl.uk/bld/PlaceOrder.do?UIN=076419 449\&ETOC $=$ RN\& from $=$ searchengine

15. Kohlberg, L. and E. Turiel, 1971. Moral Development and Moral Education. In: Psychology and Educational Practice, Lesser, G. (Ed.) Scott Foresman, Chicago, pp: 410-465. http://books.google.com.pk/books?id=_vdaAAAA CAAJ\&dq=Psychology+and+Educational+Practice

16. Rawls, John, 1971. A Theory of Justice. Harvard University Press, Cambridge, MA., ISBN: 0674880145 , pp: 607. 
17. Carifio, J., 2001. Critical analysis methodology. Proceeding of the Annual Conference on Eastern Educational Research Association. Hilton Head, NC.

18. Piaget, J. and B. Inhelder, 1969. The Psychology of the Child. Basic Books, New York, pp: 173. http://books.google.com.pk/books?id=B3YuAAA AMAAJ\&q=The+Psychology+of+the+Child\&dq= The+Psychology+of+the+Child\&pgis $=1$

19. Erikson, E.H., 1950. Childhood and Society. Norton, New York, ISBN: 039331068X pp: 397.

20. Carifio, J., 2005. Towards a standard integrated information processing/cognitive model of learning. Proceeding of the Paper Presented at the 8th Biennial Conference of the International History, July 15-18, Philosophy and Science Teaching Group, Leeds, England, pp: 1-30. http://www.ihpst2005.leeds.ac.uk/papers/Carifio.pdf

21. Erikson, L., 2006. Three models of citizenship education. Unpublished Doctoral Dissertation, University of Massachusetts, Lowell, CN: 2006, ED-12.

22. McElroy, J.H., 1999. American Beliefs. Ivan R. Dee Publisher, Chicago, ISBN: 1566633141 pp: 324.

23. Immanuel, K., 1900. Kant on Education. Translated by Annete Churton, DC Heath and Co., Boston, ISBN: 0486432211pp: 121.

24. Kuhn, T., 1962/1996. The Structure of Scientific Revolutions. 3rd Edn., University of Chicago Press, Chicago, IL, 0226458083 pp:286.

25. Kuhn, T., 1977. The Essential Tension. University of Chicago Press, Chicago, ISBN: 0226458067, pp: 390.

26. Elshtain, J.B., 1995. Democracy on Trial. Basic Books, New York, ISBN: 0465016162, pp: 153.

27. Moreau, J., 2003. Schoolbook Nation: Conflicts Over American History Textbooks from the Civil War to the Present. University of Michigan Press, Michigan, ISBN: 0472113429, pp: 403.

28. Banks, J.A., 1993. Integrating the Curriculum with Ethnic Content: Aproaches and Guidelines. In: Multicultural Education: Issues and Perspectives, Banks, J.A. and C.A. McGee-Banks (Eds.). Allyn and Bacon, Boston, ISBN: 0205140440, pp: 189-207.

29. Sleeter, C., 1996. Advanced" Ideas about democracy: Toward a pluralist conception of citizenship education. Teachers College Record, 98: 104-125.

http://direct.bl.uk/bld/PlaceOrder.do?UIN=021431 $564 \&$ ETOC $=$ RN\& from $=$ searchengine

30. Anyon, J., 1979. Ideology and the United States history textbooks. Harvard Educ. Rev., 49: 361-368. http://eric.ed.gov/ERICWebPortal/custom/portlets/ recordDetails/detailmini.jsp?_nfpb=true\&_\&ERIC ExtSearch_SearchValue_0=EJ219214\&ERICExtS earch_SearchType_0=no\&accno=EJ219214
31. Chester, F., 2003. Terrorists, Despots and Democracy: What Our Children Need To Know. The Thomas B. Fordham Foundation, Washington, DC., $\quad$ pp: 108. http://books.google.com.pk/books?id=TIqXHAAA CAAJ\&dq=Terrorists, + Despots+and+Democracy: + What+Our+Children+Need+To+Know.

32. Sasson, S., 1999. Globalization and its Discontents. New Press, New York, ISBN: 1565845188, pp: 288.

33. Lakatos, I., 1970. Falsification and the Methodology of Scientific Research Programs. In: Criticism and the Growth of Knowledge, Lakatos, I. and A. Musgrave (Eds.). Cambridge University Press, Cambridge, UK., ISBN: 0521096235, pp: 309-330.

34. Cutler, D., 2002. Taking the Initiative: Promoting Young People's Involvement in Political Decision Making. Carnegie, Washington, DC., pp: 243. http://www.amazon.co.uk/TAKING-INITIATIVEPROMOTING-PEOPLE-SINVOLVEMENT/dp/B000Z5Y2X6

35. Damon, W., 1998. Political development for a democratic future: A commentary. J. Soc., 54: 621-627. http://cat.inist.fr/?aModele $=$ afficheN\&cpsidt $=9908$ 639

36. Hahn, C., 1998. Becoming Political: Comparative Perspectives on Citizenship Education. SUNY Press, Albany, ISBN: 0791437485, pp: 304.

37. Banks, J.A., 1990. Citizenship education for a pluralistic democratic society. Soc. Stud., 81: 210-214. http://www.eric.ed.gov/ERICWebPortal/custom/po rtlets/recordDetails/detailmini.jsp?_nfpb=true\&_\& ERICExtSearch_SearchValue_0=EJ419176\&ERIC ExtSearch_SearchType_0=no\&accno=EJ419176

38. Banks, J.A., 2004. Teaching for social justice, diversity and citizenship in a global world. Educ. Forum, 17: 23-36.

http://depts.washington.edu/centerme/Fs04banks.p df

39. Baptiste, H.P., 1979. Multicultural Education: A Synopsis. 2nd Edn., University Press of America, Washington DC., ISBN: 0810108510, pp: 95.

40. Nieto, S., 1992. Affirming Diversity: The Sociopolitical Context of Multicultural Education. Longman, New York, ISBN: 0205529828, pp: 496.

41. Kymlicka, W., 1995. Multicultural Citizenship. Oxford University Press, Oxford, ISBN: 0198290918 pp: 296.

42. Parekh, B., 2000. Rethinking Multiculturalism: Cultural Diversity and Political Theory. Macmillan, New York, USA., ISBN: 1403944539 pp: 432. 
43. Hollinger, D.A., 1997. National solidarity at the end of the twentieth century: Reflections on the United States and liberal nationalism. J. Am. History, 84: 559-569. http://direct.bl.uk/bld/PlaceOrder.do?UIN=032749 963\&ETOC $=$ RN\& from $=$ searchengine

44. Popper, K.R., 1969. Conjectures and Refutations: The Growth of Scientific Knowledge. Routledge and Kegan Paul, London, UK., ISBN: 0415285941, pp: 608 .

45. Damon, W. and N. Eisenberg, 2001. Handbook of Child Psychology: Social, Emotional and Personality Development. 5th EdN., Vol. 3, Wiley, New York, ISBN: 047134981X, pp: 389-462.

46. Barbara, R.E., 2004. American cultural transfer. Gender History, 16: 146-171, http://www3.interscience.wiley.com/journal/11879 0875/abstract

47. Roni, E., 1998. Having their say: Success and persistence in mathematics. Unpublished Dissertation at College Park: University of Maryland. http://hdl.handle.net/1903/3819

48. Alice, F., 2002. Research, development and critical interculturalism. Social Science Research Centre, Dublin. http://www.ucd.ie/ssrc/interculturalism.doc

49. Brian, B., 2002. Culture and Equality: An Egalitarian Critique of Multiculturalism. Harvard University Press, Cambridge, ISBN: 0674010019, pp: 399.

50. John, F., 2002. Liberal democracy Vs transnational progressivism. Orbis, 3: 452-479. DOI: 10.1016/S0030-4387(02)00126-6

51. Gutmann, A. and D. Thompson, 2004. Why Deliberative Democracy? Princeton University Press, New Jersey, ISBN: 0691120196, pp: 217.

52. Nino, Carlos, 1998. The Constitution of Deliberative Democracy. Yale University Press, New Haven, ISBN: 0300077270, pp: 264.
53. Ravitch, D. and Viteritti, J., 2001. Making Good Citizens: Education and Civil Society. Yale University Press, New Haven, ISBN: 0300088787, pp: 368.

54. Gutmann, A., 1987. Democratic Education. Princeton University Press, Princeton, New Jersey, ISBN: 0691077363, pp: 334.

55. Macado, S., 1999. Diversity and Distrust: Civic Education in a Multicultural Democracy. Harvard University Press, Cambridge, MA., ISBN: 0674213114, pp: 368.

56. Driver, R., H. Asoko, J. Leach, E. Mortimer and P. Scott, 1994. Constructing scientific knowledge in the classroom. Educ. Res., 23: 5-12. http://www.sedl.org/pubs/classroomcompass/cc_v1n3.pdf

57. Chi, M.T.H., J.D. Slotta and N.D. Leeuw, 1994. From things to processes: A theory for conceptual change for learning science concepts. Learn. Instruct., 4: 27-43. DOI: 10.1016/09594752(94)90017-5

58. Bruner, J., 1974. Towards a Theory of Instruction. Belknap Press, Cambridge, MA., ISBN: 0674897013, pp: 192.

59. Carifio, J. and R.J. Perla, 2006. Toward the decline and fall of radical and educational constructivism (Mark 1). Proceeding of the Annual Meeting on Eastern Educational Research Association, Hilton Head, SC., pp: 1-8. http://gse.uml.edu/carifio/Jimradical-constructivism\%20paper-FOR-WEBAbode-pdf.pdf 